\title{
PAUL RICOEUR'S AESTHETICS: TRADITION AND INNOVATION
}

There is a sensation both of arrival and of prospect, so that one does indeed seem to 'recover a past and prefigure a future', and thereby to complete the circle of one's being. ${ }^{1}$

In his Poetics Aristotle argues that mimesis is a capacity, or a potentiality, rooted in nature and realised by human nature as a congenital property of humankind's natural mode of constructing and inhabiting the universe. Thus understood mimesis is the origin of art as imitation. This ancient view of the origin and nature of art has been largely discredited in modern times. Yet Paul Ricoeur offers what I find to be a bold rehabiliation of Aristotle's doctrine of mimesis, as well as a rereading of Immanuel Kant. My contention is that Ricoeur aims to restore meaning to aesthetic tradition and, at the same time, to signify something new in the pregnant present vis-à-vis the immanent future. I intend to elucidate the tensions between tradition and innovation in Ricoeur's hermeneutic phenomenology in order to uncover the precise nature of his aesthetics.

From the outset we might wonder about the cogency of Ricoeur's aesthetics uniting as it does conflicting Aristotelian and post-Kantian traditions (including Hegel, possibly Schiller, Husserl and Arendt). In fact Ricoeur's account of the origin and nature of the work of art seems to exhibit an un-Aristotelian emphasis in that he introduces a post-Kantian account of the human imagination. Ricoeur connects mimesis to a principle of the human cognitive project of reshaping reality 
modelled on both Kant's category of productive imagination in the Critique of Pure Reason and Kant's idea of reflective judgement in the Critique of Judgement.

However, potentially more problematic for many contemporary theorists is the fact that Ricoeur aims to restore meaning to the very aesthetic discourse which has become the object of modern and postmodern critiques. I need only mention any one of the various, equally radical, critiques posed by Marxists, poststructuralists and feminists of either Aristotelian metaphysics or Kantian aesthetics to recognise the formidable challenges which inevitably face Ricoeur's appropriation of these traditions. In order to address these potentially destructive criticisms I will reconstruct Ricoeur's aesthetics, taking into account his most recent work in Time and Narrative, I-III and Soi-même comme un autre.

To begin I need a frame of reference. It is possible to recognise various aesthetic theories which have, in the course of Western intellectual history, constituted different accounts of what it is that all works of art share which gives them their value. In recent discussions four elements have been distinguished as relevant for assessing a work of art: the work, the artist, the universe and the audience. Using these elements four main types of theories may be proposed. First, the mimetic theory is based upon the relation of the work of art to the universe; second, the expressive theory is based upon the relation of the work to the artist; third, the pragmatic theory is concerned with the relation of the work to the audience; fourth, the objective theory is concerned solely with the relation of the work to itself as a purely autonomous object.

Consistent with my opening statement the mimetic theory explains art as essentially an imitation of aspects of the universe. This is probably the most primitive aesthetic theory. Yet the mimetic as well as the expressive approaches to art have been intellectually delegitimated by certain contemporary theorists. The deconstructionists insist that all 
there is is the autonomous work, i.e., the text imitates nothing outside itself; other postmodernists exhibit an overriding pragmatic concern with the affect upon the audience. Notwithstanding these views a combination of all four theories informs Ricoeur's account of aesthetic value.

We can see this combination of elements by considering, however schematically, Ricoeur's account of mimesis 1-3. Mimesis1 as the prefiguration of human action encompasses elements of both the mimetic and the expressive theories of aesthetics. It involves the structural, symbolic and temporal resources which make possible the poetic composition of a work. For instance the semantics of action, norms of society and circumstances of history would all be constitutive elements of prefiguration. ${ }^{2}$ Mimesis 2 as the configuration of experience would seem to incorporate mimetic theory and objective theory, especially the Aristotelian and the Kantian conceptions of the work of art. The work imitates human reality in such a manner to liberate the reader/audience; the work exhibits objective/formal qualities which make possible the judgement of its beauty as communicating an universal delight. ${ }^{3}$ Mimesis3 as the refiguration of human praxis brings together the mimetic and the pragmatic theories. Narrative refiguration, whether historical or fictional, aims to mediate the world of the text and the world of the reader. ${ }^{4}$ Concerning the poetics of refiguration Ricoeur claims that

\footnotetext{
A new element enriching poetics arises here out of an 'aesthetics'...if we restore to the term 'aesthetic' the full range of mearing of the Greek word aisthesis and if we grant to it the task of exploring the multiple ways in which a work, in acting on a reader, affects that reader. This being-affected has the noteworthy quality of combining in an experience of a particular type passivity and activity. ${ }^{5}$
}

From Ricoeur's account of the prefiguration, configuration and refiguration of experience $I$ would conclude that mimesis is a function of human beings who, as dual-aspect beings, must mediate passivity and 
activity, sensibility and understanding, finitude and infinitude, transience and permanence. Following Aristotle mimesis is a natural mode of constructing and inhabiting the world; yet in more modern terms the threefold mimesis also aims to mediate time, i.e. historical experience and eternity, i.e. transsignifying possibilities. ${ }^{6}$

To give the modern background to Ricoeur's aesthetics. I will acknowledge his major debt to Kant who offers the first intellectual definition of aesthetics as an autonomous field of philosophy. Admittedly Alexander Gottlieb Baumgarten (1714-62) and his Aesthetica (1750-58) immediately predate Kant (1724-1801) and his Critique of Judgement (1790). Writing prior to Kant Baumgarten defines aesthetics in terms of the apprehension of sense phenomena; and he introduces concepts for evaluation of beauty as phenomenal perfection. However, Kant formulates the characteristically modern definition of aesthetics as an autonomous dimension uniting two different aspects of conscious experience. Kant argues that the unifying act is performed by the faculty of judgement, 'which in the order of our cognitive faculties forms a middle term between understanding and reason'; such judgement is governed by independent and a priori principles which constitute aesthetics as a special dimension. ${ }^{7}$

Let us further recall Kant's position. After the first two critiques, in which Kant reveals the a priori foundations of knowledge and morality, respectively, there remains a task of not only unifying the critical project through a study of judgement, but also of demonstrating the legitimacy of judgements of taste, and in particular the type of reflective judgement characteristic of aesthetics. Kant offers an analytic and a deduction that demonstrates the a priori ground of this distinctive type of judgement. Aesthetic judgements are not to be confused or identified with knowledge of the phenomenal world nor with the activity of pure practical reason. But this does not imply that such judgements are merely idiosyncratic. They make a definite claim to universality or, as Ricoeur stresses, communicability: 
a central theme in Kantian aesthetics [is] that communicability constitutes an intrinsic component of the judgement of taste.

And yet Kant stresses that "the judgement of taste... is not a cognitive judgement, and so not logical, but is aesthetic - which means that it is one whose determining ground cannot be other than subjective." 9 Throughout Kant maintains a basic dichotomy between the subjective and the objective, although he transforms the meaning of these terms.

Now Ricoeur's post-Kantian contention is that the narrative operation of mimesis 2 has the character of a judgement, more precisely, of a reflective judgement in Kant's sense of the term. That is narrative configurations function to unify a temporal succession. In Ricoeur's words,

\begin{abstract}
the art of narrating is reflected... in the attempt to grasp together' successive events. The art of narrating, as well as the corresponding art of following a story, therefore require that we are able to extract a configuration from a succession [yet] ...the primary concern is with the worlds ...authors and texts open up. ${ }^{10}$
\end{abstract}

So conceived Ricoeur's restoration of aesthetic discourse gives value to both the temporal succession - found in Kant's account of human experience - and the dramatic unity - found in Aristotle's account of emplotment. ${ }^{11}$ These two accounts are reflected in the configurational acts which incorporate, as a product of time, the story of a community. ${ }^{12}$ Moreover Ricoeur's hermeneutics of restoration endeavours to disclose the social implications of narrative configurations. Still we might question this position. One fundamental problem is that Ricoeur's configurational act aims to marry an historical account of Aristotelian mimesis - with the implicit relativism of an apparently archaic metaphysics - and the special cognitive values assigned to his post-Kantian rereading of mimesis. 
To answer this question I would place Ricoeur's aesthetics in the context of a post-Hegelian Kantian tradition - this is consistent with his own self-description. ${ }^{13}$ In particular there are striking similarities between Ricoeur's aesthetics and the account which Jürgen Habermas gives of Schiller's relation to Kant and Hegel in The Philosophical Discourse of Modernity. Habermas maintains,

\begin{abstract}
Kant's Critique of Judgement... provided an entry for a speculative Idealism that could not rest content with the Kantian differentiations between underistanding and sense, freedom and necessity, mind and nature, because it perceived in precisely these distinctions the expression of dichotomies inherent in modern life-conditions. But the mediating power of reflective judgement served Schelling and Hegel as the bridge to an intellectual intuition that was to assure itself of absolute identity. Schiller was more modest. He held on to the restricted significance of aesthetic judgement in order to make use of it for a philosophy of history. He thereby tacitly mixed the Kantian with the traditional concept of judgement, which in the Aristotelian tradition (down to Hannah Aren! wer completely lost its connection with the political coni. ommon sense. So he could conceive of art as primarily a form of communication and assign to it the task of bringing about 'harmony in society. ${ }^{14}$
\end{abstract}

A point similar to that made of Schiller could be made of Ricoeur: he mixes the Kantian concept of judgement with the Aristotelian as it comes down to Hannah Arendt. In his preface to Arendt's Condition de l'homme modeme Ricoeur recognises the value of her conception of history, action and mimesis. Arendt wants to retain the Greek account of mimesis as a creative imitation of action in its political dimension; Ricoeur extends this mimesis to narrative configuration modelled upon Kant's idea of aesthetic judgement. Furthermore Ricoeur, following Arendt, wants to resist a modern tendency to replace a concrete political conception of mimesis with a speculative - Hegelian - conception of history. 15 
Granted Ricoeur's rehabiliation of Aristotle with its post-Kantian dimensions involves complex matters. Not the least of these matters are the difficulties which attend subject-orientated theories including, crucially, what guarantees the security and the authority of the cognitive categories of the knowing (Kantian) subject. Ricoeur himself wrestles with this question of the subject in terms of narrative identity. ${ }^{16}$

An alternative reading of Ricoeur is through Husserl's later phenomenology, that is, through locating the knowing subject in the intersubjective relations of the social world. Here cognition, and hence mimesis, have their roots in what is humanly and socially shared; there is no symbolic creation which is not in the final analysis rooted in the common symbolical ground of humanity. And Ricoeur clearly owes a debt to the phenomenological tradition for elucidating the meaning of the lived experiences of time. We will see that Ricoeur gives a further function to the imagination: in phenomenological terms imaginative variations make possible the opening up of actual and possible worlds.

For me a reading of Ricoeur sensitive to his continuing debt to Husserl as well as to Kant - besides Aristotle - also makes sense of his original project in Freedom and Nature. Ricoeur's project for a philosophy of the will presupposes both Kant's conception of natural causality as a necessary objective order of temporal succession and Husserl's subjective analysis of internal-time consciousness. For instance,

\footnotetext{
Time is the form according to which the present changes constantly as to its content... it is the order of succession of moments... should we say that the marks of subjectivity attach only to acts bound by the succession? [instead] succession represents the fundamental bipolarity of human existence... it is undergone and carried on. ${ }^{17}$
}

The above reflects Kantian and Husserlian presuppositions concerning the rational subject's relation to time. These presuppositions equally characterise the aporia of Time and Narrative, III. It follows from 
Ricoeur's account of a dual-aspect being that mimesis is a necessary function for mediation of freedom and necessity.

In order to see the development of this account of temporal experience for aesthetics let us turn to Soi-même comme un autre. By confronting the problem of self i. ity Ricoeur is able to recognise further aspects of human freedom and natural necessity. For one thing, he places narrative activity in a position comparable to the fragile mediation between the extremes of infinitude and finitude which is described in Fallible Man. The significant contribution of Soi-même to contemporary debates about personal identity is in drawing a post-Kantian distinction between being the same (idem) and being the self-same (ipse). On this basis Ricoeur introduces narrative identity as a function of ipséité into the temporal milieu between permanence and change. ${ }^{18}$

For another thing, Ricoeur develops the Husserlian art of imaginative variation. He uses this art in order to demonstrate the ways in which mimesis offers the possibility of articulating the relationship between the space of experience and the horizon of expectation. Narrative identity oscillates between the two extremes of possibility and actuality, of world of text and world of audience. ${ }^{19}$

An objection to the coherence of my reading needs to be addressed. If compared with other reconstructions of Kant's contribution to contemporary aesthetic theory, Ricoeur's refusal to accept an aesthetic which depends upon a subjective account of individual genesis or taste may be thought to be contradictory. Notably Ricoeur conceives the aesthetic value of myth as the communal work of constructing an intelligible world, as a symbolic creation which is in the final analysis rooted in the common symbolic ground of humanity and as the symbolic exploration of our relationship to beings and to Being. ${ }^{20}$ This conception is not able to be reconciled with aesthetic judgement defined - after Kant - as being subjective, disinterested, unconnected with desire, 
exclusive and serving no immediate practical purpose. In fact Ricoeur brings into question this definition by elucidating the aesthetic value of myth in representing the mediation of tradition and innovation.

Generally speaking philosophers since Kant have been presented with a choice of possible paths. On the one hand, analytical philosophers may choose to support aesthetics as an autonomous discourse by declaring it out of bounds so far as politics, culture and theory are concerned. In this case one would make the obvious appeal to aesthetic disinterest, to what Kant expressly states about the character of art, rather than what the whole structure of Kant's philosophy constrains him to imply. But a close and consequent critique of, for instance, aesthetics in the analytical tradition would no doubt show how real and pressing are the ideological interests that conceal themselves behind such talk of principled autonomy. To name a few ideological interests: there are questions of gender, race, ethnicity and class.

On the other hand philosophers - especially those so-called Continental - may take up the Kantian challenge, accepting the need for some articulated theory of aesthetics, politics and knowledge, though conscious of the difficulties that stand in the way of such a project. This project must inevitably lead beyond aesthetics as such to a critical accounting of interests and truth-claims which would undermine its role as an autonomous discourse.

I would insist that the originality of Ricoeur rests in his attempt to seek a mediating position between these two extremes. It is important to restate the problem which Ricoeur helps us to recognise in Kant's analysis of aesthetic judgement. Kant's problem is to explain how aesthetic judgement is related to a distinctive type of subjective aesthetic pleasure - distinct from other sorts of pleasure - and at the same time to account for the communal validity of such judgements. Kant states that the cognitive powers are in 'free play, since no definite concept restricts them to a particular rule of cognition... This state of free play of 
the cognitive faculties attending a representation by which an object is given must admit of universal communication. ${ }^{21}$ In other words Kant aims to demonstrate that aesthetic judgements are grounded in human subjectivity and yet are not merely relative to an individual subject. Taste is communal, not idiosyncratic.

I believe that a reading of Ricoeur forces us to confront the inconclusive conclusion of Kant's Critique of Judgement. This confrontation might be reduced to two questions: does the universality of taste, once it is produced, turn out to be a natural and original property of the human subject? or does the subject to which a universality of taste can appropriately be attributed turn out to be the product of a process of cultural and historical unification? And Ricoeur would seem - unwittingly or not - to have a response to these questions: he creatively preserves the tensions inherent in post-Kantian aesthetics.

On the one hand, with his discussions of prefiguration Ricoeur must admit the dependency of artistic practices on historically variable social relations conditioning both the production of works of art and the manner in which they are socially circulated and received. On the other hand, as seen above the real work lies in elucidating those aspects of a narrative configuration which liberates the author/reader and makes possible the formal qualities of the configurating act as a reflective judgement. The most that the analysis of the social relations conditioning artistic practices might accomplish is to account for the varying ways in which tradition is mediated and so ceaselessly refigured. Thus we can see in answer to criticism mentioned at the outset of this paper that

We must challenge with equal force the thesis of a narrow structuralism which forbids 'moving outside of the text' and that of a dogmatic Marxism which merely shifts onto the social plane the worn-out topos of imitatio naturae. It is on the level of a public's horizon of expectations that a work exercises... the 'creative function of the work of art'... If a new work is able to create an aesthetic distance, it is because a prior distance exists between the 
whole of literary life and everyday practice. It is a basic characteristic of the horizon of expectation of an even more basic noncoincidence, namely, the opposition in a given culture "between poetic language and practical language, imaginary world and social reality'... What we have just indicated as literature's function of social creation arises quite precisely at this point of articulation between the expectations turned toward art and literature and the expectations constitutive of everyday experience. ${ }^{2}$

The above also reflects Ricoeur's appropriation of effective history (Wirkungsgeschichte). This implies that insofar as we appropriate past experiences with an orientation to the future, the authentic present is preserved as the locus of continuing tradition and of innovation; the one is not possible without the other. Both past and future, tradition and innovation, merge into the objectivity proper to a context of effective history. Of course as Ricoeur himself recognises there are different ways of reading effective history according to continuity and discontinuity. In particular Ricoeur differs from Michel Foucault on the question of discontinuity. ${ }^{23}$

The problem remaining for Ricoeur in the light of certain postmodern theorists is to maintain a meta-aesthetic discourse. Here his answer to the postmodern critic must be in maintaining a productive relation between text and history, freedom and constraint, vision and debt. In his words,

Free from the external constraint of documentary proof, fiction is bound internally by the very thing that it projects outside itself. Free from... artists must still make themselves free for... If this were not the case, how could we explain the anguish and suffering of artistic creation as they are attested to by the correspondence and diaries of a van Gogh or a Cézanne? ...the stringent law of creation, which is to render as perfectly as possible the vision of the world that inspires the artist, corresponds feature by feature to the debt of the historian and of the reader of history with respect to the dead... The freedom of the imaginative variations is communicated only by being cloaked in the constraining power of 
a vision of the world. The dialectic between freedom and constraint, inter:ial to the creative process, is thus transmitted throughout the hermeneutical process. ${ }^{24}$

Finm this I conclude that Ricoeur's discourse on aesthetics culminates in a creative/hermeneutical process. This would be consistent with, for instance, a claim of the puetess Veronica Forrest-Thomson:

if poetry is to justify itself ... it must articulate the already-known and subject it to a reworking which suspends and questions its categories, provides alternative orderings. ${ }^{25}$

In dialectically relating tradition and innovation Ricoeur offers an aesthetics which constitutes and is constituted by the possibility of a poetic refiguration. As we have seen Ricoeur's position is not merely to re-assert an Aristotelian or a post-Kantian aesthetics; yet his constant aim is to restore meaning to both these traditions. Such restoration does $n$. nstitute a facile project. Instead it encourages an active engagement with various critiques of aesthetic tradition, including Marxist, structuralist and postmodernist critiques. This engagement is productive insofar as Ricoeur's threefold mimesis of prefiguration, configuration and refiguration reflects an endeavour to rework accepted categories in order to signify something new in the pregnant present vis-à-vis the immanent future.

Thus I see in Ricoeur's aesthetics t ntial for that poetic vision of arrival and of prospect:

to 'recover a past and prefigure a future,' and thereby to complete the circle of one's being. 


\section{NOTES}

'Seamus Heaney, The Redress of Poetry', Professor of Poetry Inaugural Lecture, University of Oxford (Oxford: Clarendon Press, 1990), p. 12.

2Ricoeur, Time and Narrative, I, trans. Kathleen McLaughlin and David Pellauer (Chicago: University of Chicago Press, 1984), pp. 53-64.

${ }^{3}$ Ricoeur, Time and Narrative, III, trans. Kathleen Blamey and David Pellauer (Chicago: University of Chicago Press, 1988), p. 176.

${ }^{4}$ Ibid., pp. 99-102.

SIbid., p. 167.

${ }^{6}$ Ibid., pp. 270-74.

${ }^{7}$ Kant, The Critique of Judgement, trans. by James Creed Meredith (Oxford: Clarendon Press, 1957), p. 4.

${ }^{8}$ Ricoeur, Time and Narrative, III, op. cit., p. 179.

${ }^{9}$ Kant, Critique of Judgement, op. cit., pp. 41-42.

${ }^{10}$ Ricoeur, The Narrative Function', in John Thompson (ed.), Hermeneutics and the Human Sciences (Cambridge: Cambridge University Press, 1981), pp. 278-79; Time and Narrative, I, op. cit., p. 45 \& 76. Cf. Kant, The Critique of Judgement, op. cit., Book I, secs 8 \& 9.

${ }^{11}$ Ricoeur, Time and Narrative, I, op. cit., p. 64-70; and Soi-même comme un autre (Paris: Editions du Seuil, 1990), pp. 168-75.

${ }^{12}$ Ricoeur, 'The Narrative Function', op. cit., pp. 286-96.

${ }^{13}$ Ricoeur, 'Freedom in the light of Hope' in Don Ihde (ed.), Conflict of Interpretations: Essays in Hermeneutics (Evanston: Northwestern University Press, 1974), pp. 412-23; and Time and Narrative, III, op. cit., pp. 215 and 258-59.

${ }^{14}$ Jürgen Habermas, The Philosophical Discourse of Modernity, trans. Frederick Lawrence (Cambridge: Polity Press in association with Basil Blackwell, 1987), p. 48. 
${ }^{15}$ Hannah Arendt, Condition de l'homme moderne, (Paris: Calmann-Levy, 1983), pp. 23-30.

${ }^{16}$ Time and Narrative, III, op. cit., pp. 246-49, 267 \& 272.

${ }^{17}$ Ricoeur, Freedom and Nature: the Voluntary and the Imvoluntary, trans. Erazim Kohak (Evanston: Northwestern University Press, 1966), pp. 151-52.

${ }^{18}$ Ricoeur, Soi-méme comme un autre, op. cit., pp. 144-45n \& 150.

${ }^{19}$ Ibid., pp. 175-80n \& 191.

${ }^{20}$ Ricoeur, 'Structure and Hermeneutics' in Don Ihde (ed.), Conflict of Interpretations: Essays in Hermeneutics, op. cit., pp. 27-61.

${ }^{21}$ Kant, The Critique of Judgement, op. cit., p. 58.

${ }^{22}$ Ricoeur, Time and Narrative, III, op. cit., p. 173.

${ }^{23}$ Ibid., pp. 216-29.

${ }^{24}$ Ibid., p. 177.

${ }^{25}$ Veronica Forrest-Thomson, Poetic Artifice: A Theory of Twentieth-Century Poetry (Manchester: Manchester University Press, 1978), p. 53. 